\title{
Vitamin D Supplementation Could Potentially Reduce Risk of COVID-19 Infections and Deaths
}

\author{
Jing Qin Tay ${ }^{1}$, Ajay L Mahajan², and M Julie Thornton ${ }^{2}$ \\ ${ }^{1}$ Bradford Teaching Hospitals NHS Foundation Trust \\ ${ }^{2}$ University of Bradford
}

May 18, 2020

\begin{abstract}
Vitamin D has long been known to be a major regulator for both the endocrine and the immune system. With the advent of COVID-19 pandemic, there has been a growing interest in looking at the feasibility of using vitamin D as a preventative and therapeutic option in the management of the disease. A low serum level of vitamin D is linked to higher incidence of respiratory tract infection and disease progression. Vitamin D supplementation has proven to be effective in enhancing the immune system, strengthen lung epithelial barrier, and prevention of unchecked inflammatory response. Previous studies on the roles of vitamin $\mathrm{D}$ in managing influenza and other enveloped virus infection could shed light on the possible roles of vitamin $\mathrm{D}$ in the current pandemic. More randomised controlled trials are needed to explore the effects of vitamin D supplementation on COVID-19 infection.
\end{abstract}

\section{Review Criteria:}

Papers published in the MEDLINE and EMBASE databases were reviewed for evidence relating viral and respiratory tract infections to vitamin $\mathrm{D}$ deficiency; the effects of vitamin $\mathrm{D}$ supplementation on the immune and inflammatory responses; and ongoing trials on the use of vitamin D in managing COVID-19 illness. The findings were discussed and dose recommendation for vitamin D supplements summarised.

\section{Message for the Clinic:}

Vitamin D could be a readily accessible and cost-effective adjuvant therapy for COVID-19 that deserves further research.

\section{Introduction}

The outbreak of COVID-19 started at Wuhan City of China in December 2019. It has spread at a remarkable speed to countries all around the world. There is now a race to find an effective vaccine and therapy. COVID-19 is an enveloped, single-stranded, positive-sense RNA virus, which belongs to the coronavirus family. The crown-like appearance of COVID-19 is due to the presence of spike glycoproteins on the surface envelope(1). It is the seventh member of the coronavirus family that is able to infect humans(2). This virus is phylogenetically related to previously known severe acute respiratory syndrome coronavirus (SARS-CoV) 
and the Middle East respiratory syndrome coronavirus (MERS-CoV)(3). Symptoms associated with COVID19 are fever, persistent dry cough, breathlessness and lethargy; with a minority of patients suffering from headache, haemoptysis, diarrhoea, erythematous rash and urticaria(4-6). Severe cases of COVID-19 may progress to pneumonia, acute respiratory distress syndrome (ARDS) and multi organ failure(4). In terms of mortality rate, COVID-19 ranked the third in the family of coronavirus related death, compared to MERS$\mathrm{CoV}$ with a reported mortality rate of $37 \%$ and SARS-CoV of $10 \%(5)$. To date, there are over four millions confirmed cases of COVID-19, with a fatality rate of just over 300,000(7). At present, there is no definitive therapy for COVID-19. Most of the therapeutic options come from previous experience in managing SARS and MERS epidemics. Different regimes have been proposed, including the use of type 1 interferon (IFN-I), hydroxychloroquine, Ritonavir/lopinavir, Remdesivir, and neutralising antibodies (Nabs)(8). While waiting for the development of an effective vaccine, there has been ongoing research looking at alternatives that may help in the management of COVID-19 patients. Vitamin C, vitamin D, and Zinc have all been investigated as potential adjuvant therapies $(9,10)$.

Vitamin D in particular, has been in the spotlight recently. The prevalence of vitamin D deficiency is increasing, with some studies labelling it as a pandemic $(11,12)$. There is now an abundance of evidence in the literature highlighting the consequences of vitamin $\mathrm{D}$ deficiency, and its association with a variety of acute and chronic illnesses including autoimmune disease, cardiovascular disease, cancers, diabetes mellitus and neurological disorders $(13,14)$. Traditionally, vitamin D is known as the "sunshine vitamin", sunlight being the main source. 7-dehydrocholesterol in the skin is converted to cholecalciferol. It then undergoes further hydroxylation in the liver and kidney before becoming the biological active form, 1,25-dihydroxyvitaminD $\left(1,25(\mathrm{OH})_{2} \mathrm{D}\right)$, also known as calcitriol(15). $1,25(\mathrm{OH})_{2} \mathrm{D}$ activates the vitamin $\mathrm{D}$ receptor (VDR), which is a nuclear receptor, to exert its functions. It is now known that VDR is highly expressed in most cell types, suggesting the myriad of regulatory roles vitamin D plays in maintaining healthy functioning of our body(16) (Figure 1). In particular, there is strong evidence supporting the role of vitamin $\mathrm{D}$ in regulating the immune $\operatorname{system}(17)$.

Unfortunately, sunlight alone is a not a reliable source of vitamin D, especially among those living at high latitudes, ethnicity with darker skin colour and the institutionalised population(18). In high human density habitations, a lack of open spaces and high pollution has led to a decrease in direct sunlight exposure(18). To counteract this problem, vitamin D supplementation has been recommended. Research studies have shown that vitamin D supplement is effective in raising serum level of vitamin $\mathrm{D}(19,20)$. Vitamin $\mathrm{D}$ supplement helps to strengthen the immune response and plays a vital role in respiratory illness prevention, among its many other health benefits $(17,21)$. This paper discusses the roles of vitamin $\mathrm{D}$ in reducing the risk of viral infections and mitigating the severity of disease progression. More importantly this paper investigates the feasibility of using vitamin D as an adjuvant therapy in alleviating some of the symptoms associated with pneumonia and acute respiratory distress syndrome (ARDS) that lead to a poorer outcome among COVID-19 patients. This paper also discusses whether vitamin D could play any role in reversing disease progression and the prevention of COVID-19 in the general population.

\section{Methods}

We conducted a review of the evidence relating viral and respiratory tract infections to vitamin D deficiency. We searched for papers investigating the effects of vitamin D supplementation on the immune and inflammatory responses. Finally, we reviewed all articles related to COVID-19 and registered trials on the use of vitamin D in managing COVID-19 illness. All relevant entries on MEDLINE and EMBASE databases up to May 2020 were included in the discussion. 


\section{Vitamin D Reduces Risks of Viral Infection by Enhancing The Immune Response and Maintaining Integrity of Epithelial Barriers}

Vitamin D is a fat-soluble steroid hormone(22). Vitamin D modulates both the innate and adaptive immune response(23-26). In the context of disease prevention, vitamin D enhances macrophage activation, phagocytic response and production of antimicrobial peptides to stimulate the innate immune response $(17,27)$. It is known that vitamin $\mathrm{D}$ can suppress the infectiveness of a variety of enveloped virus such as the Ebola, Epstein-Barr and Hepatitis C viruses(28).Vitamin D's anti-viral mechanism is mainly attributable to its effects in the upregulation of anti-microbial peptides such as cathelicidins (LL37) and human beta defensins 2(28). Cathelicidins and defensins act by perturbing the cell envelope of the virus, binding lipopolysaccharide residues of commensal bacteria, and inhibiting viral adhesion and entry(29-33). Lymphocytes, macrophages and dendritic cells all express the necessary enzymes that can metabolise vitamin D to its biological active form $(34,35)$. They are also important target cells for vitamin D as VDR is highly expressed in these cell types $(35,36)$. By regulating both $\mathrm{T}$ and $\mathrm{B}$ cells maturation and proliferation, it plays a pivotal role in mounting an immune response against viruses(34). Vitamin D also protects the integrity of epithelial cells lining the respiratory tract and stimulates epithelial repair, thereby alleviating lung injury associated with pneumonia that commonly complicates COVID-19 infection(37-39).

Vitamin D deficiency is common among acquired immune deficiency syndrome (AIDS) patients(40). Research study on a group of AIDS patients showed an increased mortality rate in patients who are vitamin D deficient $(41,42)$. The HIV virus mainly targets cluster of differentiation 4 (CD4) found on the surface of immune cells such as T helper cells, monocytes, macrophages and dendritic cells(43). The HIV virus damages and destroys these infected cells, causing a gradual depletion in CD4 positive cells, leading to immunological failure(43). There are studies which showed that vitamin D has a positive impact on improving the CD4 count in HIV patients(44). A longitudinal study in 2018 concluded that a high serum level of $25(\mathrm{OH}) \mathrm{D}$ is associated with increased CD4 count and reduces infection severity in HIV patients(45). This suggests that vitamin D supplements can enhance the recovery of human immune system. Even in AIDS patients, vitamin $\mathrm{D}$ supplementation has been shown to increase the level of circulating vitamin $\mathrm{D}$ and therefore lower the risks of bone disease and inflammation $(40,46)$. The use of vitamin D supplementation in HIV patients have been reported to increase the immune response against pathogens, improve immunologic recovery during combination antiretroviral therapy and reduce levels of inflammation $(47,48)$. Furthermore, vitamin D supplementation has been shown to reduce HIV and Hepatitis C susceptibility by inhibiting viral entry into human cells(49-52). With regards to COVID-19, vitamin D supplementation has been shown to reduce human dipeptidyl peptidase-4 receptor (DPP-4/CD26) expression(53). As DDP-4/CD26 is a receptor that interacts with the S1 domain of the COVID-19 spike glycoprotein for cell entry, vitamin D supplementation could potentially reduce the virulence of COVID-19 in humans(54, 55).

\section{Vitamin D Reduces Risk of Respiratory Tract Infection}

COVID-19 infection shows similar properties to the Severe Acute Respiratory Syndrome (SARS) and Middle Eastern Respiratory Syndrome (MERS)(2). However, from an epidemiology perspective, COVID-19 is far more contagious than SARS-CoV and MERS-CoV, with confirmed cases far exceeding the latter two combined(2, 56). COVID-19 involves respiratory tract illness ranging from mild, moderate to severe forms $(57)$.

Research has shown that vitamin D deficiency is a predisposing factor in respiratory tract infection (RTI)(58). RTI affect the majority of the world population. It is also the one of the main causes for hospital admission as it can progress into moderate to severe pneumonia $(59,60)$. One of the main predisposing factors for developing RTI is partial or full impairment of the immune system. Vitamin D is recognised to regulate innate and adaptive immune system by stimulating the production of antimicrobial peptides in the event of viral or bacterial infections(28). Several studies have concluded a positive correlation between low serum level of vitamin D with a higher incidence and severity of lower respiratory infection in both adults and 
children(61-65). There are also studies which showed that vitamin D supplement helps to lower the rate of development of lower respiratory tract infection, especially in winter when there is a scarcity of sunlight(66, 67). However, there are some studies which showed no beneficial effects of short-term bolus doses of vitamin D supplement on the incidence and resolution of pneumonia(68-70). The mixed findings may be explained by different ages at study enrolment and severity of pneumonia, with children at the younger extreme of age having not fully developed immune system associated with poorer outcomes(61). A large European study has also shown that correcting serum level of $25(\mathrm{OH}) \mathrm{D}$ has beneficial effects on prevention of RTI and reducing disease severity in adults(71). A randomised controlled trial in Japan looking at the effects of vitamin D supplement on prevention of seasonal influenza A showed that taking 1200 international units (IU) of vitamin D per day has a $58 \%$ relative risk reduction of influenza A incidence in school children compared to the placebo group $(72)$.

Epidemiological and observational studies have linked vitamin D deficiency with the spread of RTI and other infectious diseases $(63,73-76)$. It has been seen that vitamin D deficiency is common among children below the age of five, which coincides with the prevalence of lower respiratory tract infection (LRTI), respiratory syncytial virus (RSV), and related human metapneumovirus (hMPV) infections(77). Reviews of serum vitamin $\mathrm{D}$ levels among the paediatric population in America shows a correlation between low serum vitamin D with LRTI and RSV severity(78). Another large scale study of the paediatric population in Middle Eastern countries further showed that children who have a low serum level of vitamin D are usually tested positive for RSV infection(79). There are studies which suggested that vitamin D deficiency is an important predisposing factor for developing community-acquired pneumonia and stroke-associated pneumonia (SAP)(80). A low serum level of vitamin $\mathrm{D}$ is associated with poorer disease progression in all types of acquired pneumonia including viral pneumonia, streptococcal pneumonia, and Legionella pneumonia(81). Granulomatosis with polyangiitis is an autoimmune disease characterised by vasculitis that primarily affects the respiratory tract and the kidneys. Vitamin D deficiency has been shown to be an important risk factor for RTI in this group of patients(82). The effects of vitamin D on lung immunity and respiratory diseases are well established(83).

\section{Vitamin D Prevents the Maladaptive Cycle of Local Inflammation and Secondary Injury that Leads to Poorer Outcomes}

A recent large-scale epidemiological study suggested a possible link between vitamin D deficiency and the severity of COVID-19 cases among patients in the USA, France and the United Kingdom(84). This study correlated the low serum level of vitamin D with a higher C-reactive protein (CRP) level in COVID-19 patients based on previous findings $(85,86)$. In fact, multiple observational and intervention studies have suggested the beneficial effects of vitamin D on reducing circulating CRP and pro-inflammatory cytokines(8690). This has a beneficial impact in lowering a heightened inflammation state that is associated with poorer outcomes(91-93). Vitamin D also modulates the renin-angiotensin cascade(94). A high expression of angiotensin converting enzyme (ACE) and angiotensin II, coupled with reduced expression of angiotensin converting enzyme 2 (ACE2) are common features in a pro-inflammatory state in acute respiratory distress syndrome (ARDS). Vitamin D reduces the susceptibility to acute lung injury (ALI) by inhibiting renin thereby angiotensin II biosynthesis(95-98). This may have a protective effect in preventing a "cytokine storm" that is often implicated in severe COVID-19 cases $(84,99)$.

Vitamin D also enhances the production of interleukin-10 (IL-10), a cytokine with potent anti-inflammatory properties(100). Increasing IL-10 favours the proliferation and differentiation of T helper cell 2 (Th2) and T regulator (T reg) cells over T helper cell 1 (Th1) and T helper cell 17 (Th 17) (101, 102). This could have an effect in promoting tolerance and controlling an exacerbated immune response(41). Furthermore, vitamin D supplementation reduces the expression of pro-inflammatory cytokines and increases the expression of antiinflammatory cytokines by macrophages, by enhancing expression of MAPK phosphatase- 1 and suppressing p38 activation(103-105). A persistent immune activation leads to an increased mortality in HIV patient. Vitamin D protects against the development of immune reconstitution inflammatory syndrome events in 
HIV patients, likely through downregulating CD38 expression on the surface of memory CD8 ${ }^{+} \mathrm{T}$ cells(106, 107). Vitamin D also decreases the expression of major histocompatibility complex (MHC) class II and their co-stimulatory molecules such as CD80, thereby decreasing $\mathrm{T}$ cell activation with persistent antigen presentation(108). It could be posited that these anti-inflammatory properties of vitamin D could have beneficial impacts on patients suffering from severe form of COVID-19.

In animal studies, it has been shown that vitamin D can reduce the severity of coronavirus illness such as

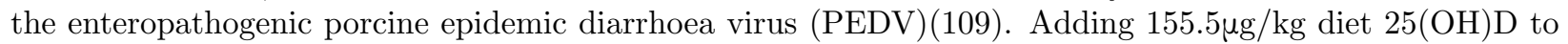
the feed given to weaned pigs can have a protective effect on PEDV-induced inflammation and alleviate damage to the intestinal tracts(109). This is achieved by regulating autophagy, enhancing cathelicidins production and inhibiting jejuna mucosa interleukin-6 (IL-6) and interleukin-8 (IL-8) mRNA expression, hence lessening the severity of damage(109-111). The VDR-knockout mice model has demonstrated that vitamin $\mathrm{D}$ has protective effects on the integrity of epithelial cells lining the respiratory tract, by reducing lipopolysaccharides-induced acute lung injury(112). These animal studies suggest that active vitamin D could be effective in reducing the severity of acute lung injury and suppress a heightened inflammatory state in COVID-19 patients.

\section{Dose recommendation for vitamin D supplements}

Unfortunately, there is no consensus on the optimal dose of vitamin D supplementation for managing viral diseases or RTI. A previous study has reported that in children suffering from recurrent respiratory tract infection, giving vitamin D supplements could reduce the number of disease occurrences in a year, with no noticeable adverse side effects, suggesting that vitamin D supplementation could be an effective adjuvant therapy in managing RTI(113). Doses ranging from $800 \mathrm{IU}$ to 100,000 IU per day have been suggested(114). When using a bolus schedule, the effects seems to be smaller(115-117). Vitamin D has been shown to be beneficial in the prevention and treatment of influenza(118). Research conducted in Japan has reported that taking $1200 \mathrm{IU}$ per day of vitamin D supplement could reduce the risk of contracting influenza by six fold(72). In terms of recommending dosage of vitamin $\mathrm{D}$ as an adjuvant therapy for influenza, it has been shown that there is a lower incidence of influenza among patients whose serum level of vitamin $\mathrm{D}$ is above $40 \mathrm{ng} / \mathrm{mL}(118,119)$. Besides that, by giving $50,000 \mathrm{IU}$ of vitamin $\mathrm{D}_{3}$ supplement once daily or $10,000 \mathrm{IU}$ of vitamin D three times a day, significantly reduced the severity of symptoms in patients who suffer from influenza after a period of seventy-two hours(120).

Vitamin D supplementation should ideally be guided by serum levels of vitamin D to avoid untoward effects. Recent trials challenged whether serum vitamin D levels of [?]30 ng/mL promote human health(121). A study by Quraishi et al (2013) found that people with vitamin D levels of less than $30 \mathrm{ng} / \mathrm{ml}$ were $56 \%$ more likely to develop community acquired pneumonia than those with levels of $30 \mathrm{ng} / \mathrm{ml}$ or higher(80). A recent paper by Grant et al (2020) suggested taking 10,000 IU per day of vitamin $\mathrm{D}_{3}$ for a few weeks as a loading dose, followed by $5000 \mathrm{IU}$ per day as a maintenance dose, in order to raise serum vitamin D level above $40-60 \mathrm{ng} / \mathrm{mL}(122)$. Indeed, a dose of up to $4000 \mathrm{IU}$ or 100 micrograms per day has been cited as a safe dose by several studies(123, 124). Public Health England (PHE) has recently recommended taking 10 micrograms of vitamin D per day as a supplement during the lockdown period(125). More randomised controlled trials and large population studies should be conducted to evaluate these recommendations(122).

\section{Conclusion}

In conclusion, the impacts of COVID 19 and its strain on the healthcare system are huge. The mortality rate is especially high in vulnerable populations that are vitamin $\mathrm{D}$ deficient. The situation is likely to be worse with the introduction of emergency lockdown measures that confines the population indoors. Vitamin D deficiency is prevalent among the U.K. population, with crude incidence rate increased from 0.29 per 1000 
person-year in 2005 to 16.08 per 1000 person-year in 2015(126). It affects one in five people in the U.K. according to a national survey(127). In the northern hemisphere, Vitamin D deficiency is often worse over the months from October to March when there is less sunlight in the day, corresponding to a peak in the spread of COVID-19. To date there are ongoing clinical trials in the U.S. and Spain involving COVID-19 patients to establish whether taking vitamin D can help in attenuating disease progression(9). The use of vitamin $\mathrm{D}$ as a readily accessible and cost-effective strategy to reduce the incidence and severity of disease in COVID-19 patients is an option that deserves further consideration.

\section{References}

1. Cascella M, Rajnik M, Cuomo A, Dulebohn SC, Di Napoli R. Features, evaluation and treatment coronavirus (COVID-19). Statpearls [internet]: StatPearls Publishing; 2020.

2. Li H, Liu S-M, Yu X-H, Tang S-L, Tang C-K. Coronavirus disease 2019 (COVID-19): current status and future perspectives. Int J Antimicrob Agents. 2020:105951-.

3. Petrosillo N, Viceconte G, Ergonul O, Ippolito G, Petersen E. COVID-19, SARS and MERS: are they closely related? Clinical microbiology and infection : the official publication of the European Society of Clinical Microbiology and Infectious Diseases. 2020.

4. Singhal T. A Review of Coronavirus Disease-2019 (COVID-19). Indian journal of pediatrics. 2020;87(4):281-6.

5. Huang C, Wang Y, Li X, Ren L, Zhao J, Hu Y, et al. Clinical features of patients infected with 2019 novel coronavirus in Wuhan, China. The Lancet. 2020;395(10223):497-506.

6. Sachdeva M, Gianotti R, Shah M, Lucia B, Tosi D, Veraldi S, et al. Cutaneous manifestations of COVID19: Report of three cases and a review of literature. J Dermatol Sci. 2020:S0923-1811(20)30149-3.

7. WHO. Coronavirus disease 2019 (COVID-19) Situation Report - 1142020 [Available from: https://www.who.int/docs/default-source/coronaviruse/situation-reports/20200513-covid-19-sitrep114.pdf?sfvrsn=17ebbbe_4.

8. Shetty R, Ghosh A, Honavar SG, Khamar P, Sethu S. Therapeutic opportunities to manage COVID19/SARS-CoV-2 infection: Present and future. Indian journal of ophthalmology. 2020;68(5):693.

9. ClinicalTrials.gov. A Study of Hydroxychloroquine, Vitamin C, Vitamin D, and Zinc for the Prevention of COVID-19 Infection: https://ClinicalTrials.gov/show/NCT04335084; 2020 [

10. Rondanelli M, Miccono A, Lamburghini S, Avanzato I, Riva A, Allegrini P, et al. Self-Care for Common Colds: The Pivotal Role of Vitamin D, Vitamin C, Zinc, and Echinacea in Three Main Immune Interactive Clusters (Physical Barriers, Innate and Adaptive Immunity) Involved during an Episode of Common ColdsPractical Advice on Dosages and on the Time to Take These Nutrients/Botanicals in order to Prevent or Treat Common Colds. Evid Based Complement Alternat Med. 2018;2018:5813095-.

11. Shah D, Gupta P. Vitamin D Deficiency: Is The Pandemic for Real? Indian J Community Med. $2015 ; 40(4): 215-7$.

12. Holick MF. The vitamin D deficiency pandemic: Approaches for diagnosis, treatment and prevention. Reviews in endocrine \& metabolic disorders. 2017;18(2):153-65.

13. Wang H, Chen W, Li D, Yin X, Zhang X, Olsen N, et al. Vitamin D and Chronic Diseases. Aging Dis. 2017;8(3):346-53.

14. Holick MF. Vitamin D: importance in the prevention of cancers, type 1 diabetes, heart disease, and osteoporosis. The American journal of clinical nutrition. 2004;79(3):362-71. 
15. Bikle DD. Vitamin D metabolism, mechanism of action, and clinical applications. Chem Biol. 2014;21(3):319-29.

16. Morris HA, Anderson PH. Autocrine and paracrine actions of vitamin d. Clin Biochem Rev. 2010;31(4):129-38.

17. Prietl B, Treiber G, Pieber TR, Amrein K. Vitamin D and immune function. Nutrients. 2013;5(7):250221.

18. Wacker M, Holick MF. Sunlight and Vitamin D: A global perspective for health. Dermatoendocrinol. 2013;5(1):51-108.

19. Vashi PG, Trukova K, Lammersfeld CA, Braun DP, Gupta D. Impact of oral vitamin D supplementation on serum 25-hydroxyvitamin D levels in oncology. Nutrition Journal. 2010;9(1):60.

20. Gowda U, Ruwanpathirana T, Fong DPS, Kaur A, Renzaho AMN. Efficacy of high dose Vitamin D supplementation in improving serum $25(\mathrm{OH}) \mathrm{D}$ among migrant and non migrant population: a retrospective study. BMC Health Services Research. 2016;16(1):579.

21. Zhang R, Naughton DP. Vitamin D in health and disease: current perspectives. Nutrition journal. 2010;9:65-.

22. Nair R, Maseeh A. Vitamin D: The "sunshine" vitamin. J Pharmacol Pharmacother. 2012;3(2):118-26.

23. Hewison M. Antibacterial effects of vitamin D. Nature Reviews Endocrinology. 2011;7(6):337.

24. Khoo AL, Chai L, Koenen H, Joosten I, Netea M, van der Ven A. Translating the role of vitamin D3 in infectious diseases. Critical reviews in microbiology. 2012;38(2):122-35.

25. Mangin M, Sinha R, Fincher K. Inflammation and vitamin D: the infection connection. Inflammation Research. 2014;63(10):803-19.

26. White JH. Vitamin D metabolism and signaling in the immune system. Reviews in endocrine and metabolic disorders. 2012;13(1):21-9.

27. Nouari W, Ysmail-Dahlouk L, Aribi M. Vitamin D3 enhances bactericidal activity of macrophage against Pseudomonas aeruginosa. International immunopharmacology. 2016;30:94-101.

28. Beard JA, Bearden A, Striker R. Vitamin D and the anti-viral state. J Clin Virol. 2011;50(3):194-200.

29. Zasloff M. Fighting infections with vitamin D. Nature medicine. 2006;12(4):388-90.

30. Turner J, Cho Y, Dinh N-N, Waring AJ, Lehrer RI. Activities of LL-37, a cathelin-associated antimicrobial peptide of human neutrophils. Antimicrobial agents and chemotherapy. 1998;42(9):2206-14.

31. Hazrati E, Galen B, Lu W, Wang W, Ouyang Y, Keller MJ, et al. Human $\alpha$ - and $\beta$-Defensins Block Multiple Steps in Herpes Simplex Virus Infection. The Journal of Immunology. 2006;177(12):8658-66.

32. Yasin B, Wang W, Pang M, Cheshenko N, Hong T, Waring AJ, et al. $\vartheta$ Defensins Protect Cells from Infection by Herpes Simplex Virus by Inhibiting Viral Adhesion and Entry. Journal of Virology. 2004;78(10):5147-56.

33. Tripathi S, Tecle T, Verma A, Crouch E, White M, Hartshorn KL. The human cathelicidin LL-37 inhibits influenza A viruses through a mechanism distinct from that of surfactant protein D or defensins. J Gen Virol. 2013;94(Pt 1):40-9.

34. Aranow C. Vitamin D and the immune system. J Investig Med. 2011;59(6):881-6.

35. Gil A, Plaza-Diaz J, Mesa MD. Vitamin D: classic and novel actions. Annals of Nutrition and Metabolism. 2018;72(2):87-95. 
36. Szymczak I, Pawliczak R. The Active Metabolite of Vitamin D3 as a Potential Immunomodulator. Scandinavian Journal of Immunology. 2016;83(2):83-91.

37. Zheng S, Yang J, Hu X, Li M, Wang Q, Dancer RCA, et al. Vitamin D attenuates lung injury via stimulating epithelial repair, reducing epithelial cell apoptosis and inhibits TGF- $\beta$ induced epithelial to mesenchymal transition. Biochemical Pharmacology. 2020:113955.

38. Dancer RCA, Parekh D, Lax S, D'Souza V, Zheng S, Bassford CR, et al. Vitamin D deficiency contributes directly to the acute respiratory distress syndrome (ARDS). Thorax. 2015;70(7):617-24.

39. Xu J, Yang J, Chen J, Luo Q, Zhang Q, Zhang H. Vitamin D alleviates lipopolysaccharide-induced acute lung injury via regulation of the renin-angiotensin system. Molecular medicine reports. 2017;16(5):7432-8.

40. Hileman CO, Overton ET, McComsey GA. Vitamin D and bone loss in HIV. Current Opinion in HIV and AIDS. 2016;11(3):277.

41. Alvarez N, Aguilar-Jimenez W, Rugeles MT. The Potential Protective Role of Vitamin D Supplementation on HIV-1 Infection. Front Immunol. 2019;10(2291).

42. Lake JE, Adams JS. Vitamin D in HIV-Infected Patients. Curr HIV/AIDS Rep. 2011;8(3):133-41.

43. Okoye AA, Picker LJ. CD 4+ T-cell depletion in HIV infection: mechanisms of immunological failure. Immunological reviews. 2013;254(1):54-64.

44. Abraham AG, Zhang L, Calkins K, Tin A, Hoofnagle A, Palella FJ, Jr., et al. Vitamin D status and immune function reconstitution in HIV-infected men initiating therapy. AIDS (London, England). 2018;32(8):1069-76.

45. Jiménez-Sousa MÁ, Martínez I, Medrano LM, Fernández-Rodríguez A, Resino S. Vitamin D in human immunodeficiency virus infection: influence on immunity and disease. Front Immunol. 2018;9:458.

46. Mansueto P, Seidita A, Vitale G, Gangemi S, Iaria C, Cascio A. Vitamin D Deficiency in HIV Infection: Not Only a Bone Disorder. Biomed Res Int. 2015;2015:735615-.

47. Jiménez-Sousa MÁ, Martínez I, Medrano LM, Fernández-Rodríguez A, Resino S. Vitamin D in Human Immunodeficiency Virus Infection: Influence on Immunity and Disease. Front Immunol. 2018;9:458-.

48. Coelho L, Cardoso SW, Luz PM, Hoffman RM, Mendonça L, Veloso VG, et al. Vitamin D3 supplementation in HIV infection: effectiveness and associations with antiretroviral therapy. Nutrition Journal. 2015;14(1):81.

49. Connor RI, Rigby WF. 1 alpha,25-dihydroxyvitamin D3 inhibits productive infection of human monocytes by HIV-1. Biochemical and biophysical research communications. 1991;176(2):852-9.

50. Schuitemaker H, Kootstra NA, Koppelman MH, Bruisten SM, Huisman HG, Tersmette M, et al. Proliferation-dependent HIV-1 infection of monocytes occurs during differentiation into macrophages. The Journal of clinical investigation. 1992;89(4):1154-60.

51. Villar LM, Del Campo JA, Ranchal I, Lampe E, Romero-Gomez M. Association between vitamin D and hepatitis C virus infection: a meta-analysis. World journal of gastroenterology. 2013;19(35):5917-24.

52. Gutierrez JA, Jones KA, Flores R, Singhania A, Woelk CH, Schooley RT, et al. Vitamin D Metabolites Inhibit Hepatitis C Virus and Modulate Cellular Gene Expression. J Virol Antivir Res. 2014;3(3):10.4172/23248955.1000129.

53. Vankadari N, Wilce JA. Emerging WuHan (COVID-19) coronavirus: glycan shield and structure prediction of spike glycoprotein and its interaction with human CD26. Emerging microbes \& infections. 2020;9(1):601-4. 
54. McCartney D, Byrne D. Optimisation of Vitamin D Status for Enhanced Immuno-protection Against Covid-19.

55. Komolmit P, Kimtrakool S, Suksawatamnuay S, Thanapirom K, Chattrasophon K, Thaimai P, et al. Vitamin D supplementation improves serum markers associated with hepatic fibrogenesis in chronic hepatitis C patients: A randomized, double-blind, placebo-controlled study. Scientific Reports. 2017;7(1):8905.

56. Hewings-Martin Y. How do SARS and MERS compare with COVID-19? [Newsletter]. MEDICALNEWSTODAY; 2020 [updated 10 April 2020. Available from: https://www.medicalnewstoday.com/articles/howdo-sars-and-mers-compare-with-covid-19.

57. Yuki K, Fujiogi M, Koutsogiannaki S. COVID-19 pathophysiology: A review. Clin Immunol. 2020:108427.

58. Martineau AR, Jolliffe DA, Hooper RL, Greenberg L, Aloia JF, Bergman P, et al. Vitamin D supplementation to prevent acute respiratory tract infections: systematic review and meta-analysis of individual participant data. BMJ. 2017;356:i6583.

59. Storms AD, Chen J, Jackson LA, Nordin JD, Naleway AL, Glanz JM, et al. Rates and risk factors associated with hospitalization for pneumonia with ICU admission among adults. BMC Pulm Med. 2017;17(1):208-.

60. Marston BJ, Plouffe JF, File TM, Jr., Hackman BA, Salstrom SJ, Lipman HB, et al. Incidence of community-acquired pneumonia requiring hospitalization. Results of a population-based active surveillance Study in Ohio. The Community-Based Pneumonia Incidence Study Group. Archives of internal medicine. 1997;157(15):1709-18.

61. Jat KR. Vitamin D deficiency and lower respiratory tract infections in children: a systematic review and meta-analysis of observational studies. Tropical doctor. 2017;47(1):77-84.

62. Berry DJ, Hesketh K, Power C, Hypponen E. Vitamin D status has a linear association with seasonal infections and lung function in British adults. The British journal of nutrition. 2011;106(9):1433-40.

63. Ginde AA, Mansbach JM, Camargo CA, Jr. Association between serum 25-hydroxyvitamin D level and upper respiratory tract infection in the Third National Health and Nutrition Examination Survey. Archives of internal medicine. 2009;169(4):384-90.

64. Sabetta JR, DePetrillo P, Cipriani RJ, Smardin J, Burns LA, Landry ML. Serum 25-hydroxyvitamin d and the incidence of acute viral respiratory tract infections in healthy adults. PLoS One. 2010;5(6):e11088.

65. Laaksi I, Ruohola JP, Tuohimaa P, Auvinen A, Haataja R, Pihlajamaki H, et al. An association of serum vitamin $\mathrm{D}$ concentrations $<40 \mathrm{nmol} / \mathrm{L}$ with acute respiratory tract infection in young Finnish men. Am J Clin Nutr. 2007;86(3):714-7.

66. Manaseki-Holland S, Qader G, Isaq Masher M, Bruce J, Zulf Mughal M, Chandramohan D, et al. Effects of vitamin D supplementation to children diagnosed with pneumonia in Kabul: a randomised controlled trial. Tropical medicine \& international health : TM \& IH. 2010;15(10):1148-55.

67. Camargo CA, Jr., Ganmaa D, Frazier AL, Kirchberg FF, Stuart JJ, Kleinman K, et al. Randomized trial of vitamin D supplementation and risk of acute respiratory infection in Mongolia. Pediatrics. 2012;130(3):e561-7.

68. Choudhary N, Gupta P. Vitamin D supplementation for severe pneumonia-a randomized controlled trial. Indian pediatrics. 2012;49(6):449-54.

69. Manaseki-Holland S, Maroof Z, Bruce J, Mughal MZ, Masher MI, Bhutta ZA, et al. Effect on the incidence of pneumonia of vitamin D supplementation by quarterly bolus dose to infants in Kabul: a randomised controlled superiority trial. Lancet (London, England). 2012;379(9824):1419-27.

70. Das RR, Singh M, Panigrahi I, Naik SS. Vitamin D supplementation for the treatment of acute childhood pneumonia: a systematic review. ISRN pediatrics. 2013;2013. 
71. Zittermann A, Pilz S, Hoffmann H, März W. Vitamin D and airway infections: a European perspective. European journal of medical research. 2016;21(1):14.

72. Urashima M, Segawa T, Okazaki M, Kurihara M, Wada Y, Ida H. Randomized trial of vitamin D supplementation to prevent seasonal influenza A in schoolchildren. Am J Clin Nutr. 2010;91(5):1255-60.

73. Kearns MD, Alvarez JA, Seidel N, Tangpricha V. Impact of vitamin D on infectious disease. Am J Med Sci. 2015;349(3):245-62.

74. Cannell JJ, Vieth R, Umhau JC, Holick MF, Grant WB, Madronich S, et al. Epidemic influenza and vitamin D. Epidemiology and infection. 2006;134(6):1129-40.

75. Karatekin G, Kaya A, Salihoglu O, Balci H, Nuhoglu A. Association of subclinical vitamin D deficiency in newborns with acute lower respiratory infection and their mothers. European journal of clinical nutrition. 2009;63(4):473-7.

76. Roth DE, Shah R, Black RE, Baqui AH. Vitamin D status and acute lower respiratory infection in early childhood in Sylhet, Bangladesh. Acta paediatrica (Oslo, Norway : 1992). 2010;99(3):389-93.

77. Hurwitz JL, Jones BG, Penkert RR, Gansebom S, Sun Y, Tang L, et al. Low Retinol-Binding Protein and Vitamin D Levels Are Associated with Severe Outcomes in Children Hospitalized with Lower Respiratory Tract Infection and Respiratory Syncytial Virus or Human Metapneumovirus Detection. J Pediatr. 2017;187:323-7.

78. Walker VP, Modlin RL. The vitamin D connection to pediatric infections and immune function. Pediatr Res. 2009;65(5 Pt 2):106R-13R.

79. Halasa N, Williams J, Faouri S, Shehabi A, Vermund SH, Wang L, et al. Natural history and epidemiology of respiratory syncytial virus infection in the Middle East: Hospital surveillance for children under age two in Jordan. Vaccine. 2015;33(47):6479-87.

80. Quraishi SA, Bittner EA, Christopher KB, Camargo Jr CA. Vitamin D status and community-acquired pneumonia: results from the third National Health and Nutrition Examination Survey. PLoS One. 2013;8(11).

81. Pletz MW, Terkamp C, Schumacher U, Rohde G, Schütte H, Welte T, et al. Vitamin D deficiency in community-acquired pneumonia: low levels of $1,25(\mathrm{OH}) 2 \mathrm{D}$ are associated with disease severity. Respiratory Research. 2014;15(1):53.

82. Perez MO, Oliveira RM, Levy-Neto M, Caparbo VF, Pereira RMR. Serum 25-hydroxyvitamin D levels in patients with Granulomatosis with Polyangiitis: association with respiratory infection. Clinics (Sao Paulo). 2017;72(12):723-8.

83. Hansdottir S, Monick MM. Chapter Nine - Vitamin D Effects on Lung Immunity and Respiratory Diseases. In: Litwack G, editor. Vitamins \& Hormones. 86: Academic Press; 2011. p. 217-37.

84. Daneshkhah A, Agrawal V, Eshein A, Subramanian H, Roy HK, Backman V. The Possible Role of Vitamin D in Suppressing Cytokine Storm and Associated Mortality in COVID-19 Patients. medRxiv. 2020:2020.04.08.20058578.

85. Robinson AB, Tangpricha V, Yow E, Gurion R, McComsey GA, Schanberg LE. Vitamin D deficiency is common and associated with increased C-reactive protein in children and young adults with lupus: an Atherosclerosis Prevention in Pediatric Lupus Erythematosus substudy. Lupus Sci Med. 2014;1(1):e000011.

86. Liefaard MC, Ligthart S, Vitezova A, Hofman A, Uitterlinden AG, Kiefte-de Jong JC, et al. Vitamin D and C-Reactive Protein: A Mendelian Randomization Study. PLoS One. 2015;10(7):e0131740-e.

87. Li Q, Dai Z, Cao Y, Wang L. Association of C-reactive protein and vitamin D deficiency with cardiovascular disease: A nationwide cross-sectional study from National Health and Nutrition Examination Survey 2007 to 2008. Clinical cardiology. 2019;42(7):663-9. 
88. Chandler PD, Scott JB, Drake BF, Ng K, Manson JE, Rifai N, et al. Impact of vitamin D supplementation on inflammatory markers in African Americans: results of a four-arm, randomized, placebo-controlled trial. Cancer prevention research. 2014;7(2):218-25.

89. Mazidi M, Rezaie P, Vatanparast H. Impact of vitamin D supplementation on C-reactive protein; a systematic review and meta-analysis of randomized controlled trials. BMC Nutrition. 2018;4(1):1.

90. Xu S, Song J, Zhang Z-H, Fu L, Gao L, Xie D-D, et al. The Vitamin D status is associated with serum C-reactive protein and adhesion molecules in patients with renal cell carcinoma. Scientific Reports. 2019;9(1):16719.

91. Robinson AB, Tangpricha V, Yow E, Gurion R, McComsey GA, Schanberg LE, et al. Vitamin D deficiency is common and associated with increased C-reactive protein in children and young adults with lupus: an Atherosclerosis Prevention in Pediatric Lupus Erythematosus substudy. Lupus science \& medicine. 2014;1(1):e000011.

92. Luo X, Zhou W, Yan X, Guo T, Wang B, Xia H, et al. Prognostic value of C-reactive protein in patients with COVID-192020.

93. Wang L. C-reactive protein levels in the early stage of COVID-19. Medecine et maladies infectieuses. 2020 .

94. McMullan CJ, Borgi L, Curhan GC, Fisher N, Forman JP. The Effect of Vitamin D on Renin-AngiotensinSystem Activation and Blood Pressure-A Randomized Control Trial. Journal of hypertension. 2017;35(4):822.

95. Li YC, Qiao G, Uskokovic M, Xiang W, Zheng W, Kong J. Vitamin D: a negative endocrine regulator of the renin-angiotensin system and blood pressure. The Journal of steroid biochemistry and molecular biology. 2004;89-90(1-5):387-92.

96. Li YC, Qiao G, Uskokovic M, Xiang W, Zheng W, Kong J. Vitamin D: a negative endocrine regulator of the renin-angiotensin system and blood pressure. The Journal of steroid biochemistry and molecular biology. 2004;89:387-92.

97. Zittermann A, Ernst JB, Prokop S, Fuchs U, Dreier J, Kuhn J, et al. Effects of vitamin D supplementation on renin and aldosterone concentrations in patients with advanced heart failure: the EVITA trial. International journal of endocrinology. 2018;2018.

98. Li Y. Vitamin D regulation of the renin-angiotensin system. Journal of cellular biochemistry. 2003;88:32731.

99. Mehta P, McAuley DF, Brown M, Sanchez E, Tattersall RS, Manson JJ. COVID-19: consider cytokine storm syndromes and immunosuppression. The Lancet. 2020;395(10229):1033-4.

100. Heine G, Niesner U, Chang HD, Steinmeyer A, Zügel U, Zuberbier T, et al. 1, 25-dihydroxyvitamin D3 promotes IL-10 production in human B cells. European journal of immunology. 2008;38(8):2210-8.

101. Adams JS, Hewison M. Update in vitamin D. The Journal of clinical endocrinology and metabolism. 2010;95(2):471-8.

102. Smolders J, Thewissen M, Peelen E, Menheere P, Tervaert JW, Damoiseaux J, et al. Vitamin D status is positively correlated with regulatory $\mathrm{T}$ cell function in patients with multiple sclerosis. PLoS One. 2009;4(8):e6635.

103. Lin Z, Li W. The Roles of Vitamin D and Its Analogs in Inflammatory Diseases. Current topics in medicinal chemistry. 2016;16(11):1242-61.

104. Zhang Y, Leung DY, Richers BN, Liu Y, Remigio LK, Riches DW, et al. Vitamin D inhibits monocyte/macrophage proinflammatory cytokine production by targeting MAPK phosphatase-1. Journal of immunology (Baltimore, Md : 1950). 2012;188(5):2127-35. 
105. Topilski I, Flaishon L, Naveh Y, Harmelin A, Levo Y, Shachar I. The anti-inflammatory effects of 1,25dihydroxyvitamin D3 on Th2 cells in vivo are due in part to the control of integrin-mediated T lymphocyte homing. European journal of immunology. 2004;34(4):1068-76.

106. Musselwhite LW, Andrade BB, Ellenberg SS, Tierney A, Belaunzaran-Zamudio PF, Rupert A, et al. Vitamin D, d-dimer, Interferon $\gamma$, and sCD14 Levels are Independently Associated with Immune Reconstitution Inflammatory Syndrome: A Prospective, International Study. EBioMedicine. 2016;4:115-23.

107. Fabre-Mersseman V, Tubiana R, Papagno L, Bayard C, Briceno O, Fastenackels S, et al. Vitamin D supplementation is associated with reduced immune activation levels in HIV-1-infected patients on suppressive antiretroviral therapy. AIDS (London, England). 2014;28(18):2677-82.

108. Baeke F, Takiishi T, Korf H, Gysemans C, Mathieu C. Vitamin D: modulator of the immune system. Current Opinion in Pharmacology. 2010;10(4):482-96.

109. Yang J, Tian G, Chen D, Zheng P, Yu J, Mao X, et al. Dietary 25-Hydroxyvitamin D(3) Supplementation Alleviates Porcine Epidemic Diarrhea Virus Infection by Improving Intestinal Structure and Immune Response in Weaned Pigs. Animals (Basel). 2019;9(9):627.

110. Tian G, Liang X, Chen D, Mao X, Yu J, Zheng P, et al. Vitamin D3 supplementation alleviates rotavirus infection in pigs and IPEC-J2 cells via regulating the autophagy signaling pathway. The Journal of steroid biochemistry and molecular biology. 2016;163:157-63.

111. Yuk JM, Shin DM, Lee HM, Yang CS, Jin HS, Kim KK, et al. Vitamin D3 induces autophagy in human monocytes/macrophages via cathelicidin. Cell host \& microbe. 2009;6(3):231-43.

112. Shi YY, Liu TJ, Fu JH, Xu W, Wu LL, Hou AN, et al. Vitamin D/VDR signaling attenuates lipopolysaccharide-induced acute lung injury by maintaining the integrity of the pulmonary epithelial barrier. Molecular medicine reports. 2016;13(2):1186-94.

113. Esposito S, Lelii M. Vitamin D and respiratory tract infections in childhood. BMC Infect Dis. 2015;15:487-.

114. Bergman P, Lindh AU, Björkhem-Bergman L, Lindh JD. Vitamin D and Respiratory Tract Infections: A Systematic Review and Meta-Analysis of Randomized Controlled Trials. PLoS One. 2013;8(6):e65835-e.

115. Heaney RP. Vitamin D-baseline status and effective dose. The New England journal of medicine. 2012;367(1):77-8.

116. Martineau AR. Bolus-dose vitamin D and prevention of childhood pneumonia. Lancet (London, England). 2012;379(9824):1373-5.

117. Hollis BW. Short-term and long-term consequences and concerns regarding valid assessment of vitamin D deficiency: comparison of recent food supplementation and clinical guidance reports. Current opinion in clinical nutrition and metabolic care. 2011;14(6):598-604.

118. Schwalfenberg G. Vitamin D for influenza. Canadian Family Physician. 2015;61(6):507-.

119. Alshahrani F, Aljohani N. Vitamin D: deficiency, sufficiency and toxicity. Nutrients. 2013;5(9):3605-16.

120. Schwalfenberg G. Vitamin D for influenza. Can Fam Physician. 2015;61(6):507-.

121. Grant WB, Al Anouti F, Moukayed M. Targeted 25-hydroxyvitamin D concentration measurements and vitamin D3 supplementation can have important patient and public health benefits. European journal of clinical nutrition. 2020;74(3):366-76.

122. Grant WB, Lahore H, McDonnell SL, Baggerly CA, French CB, Aliano JL, et al. Evidence that vitamin D supplementation could reduce risk of influenza and COVID-19 infections and deaths. Nutrients. 2020;12(4):988. 
123. Vieth R, Kimball S, Hu A, Walfish PG. Randomized comparison of the effects of the vitamin D3 adequate intake versus $100 \mathrm{mcg}$ (4000 IU) per day on biochemical responses and the wellbeing of patients. Nutr J. 2004;3:8.

124. Bischoff-Ferrari HA, Shao A, Dawson-Hughes B, Hathcock J, Giovannucci E, Willett WC. Benefit-risk assessment of vitamin D supplementation. Osteoporosis international : a journal established as result of cooperation between the European Foundation for Osteoporosis and the National Osteoporosis Foundation of the USA. 2010;21(7):1121-32.

125. Sullivan R. Coronavirus: PHE recommends taking vitamin D supplements as lockdown continues [Newspaper]. Independent; 2020 [Available from: https://www.independent.co.uk/news/health/coronaviruslockdown-uk-england-vitamin-d-intake-phe-a9479401.html.

126. Crowe FL, Jolly K, MacArthur C, Manaseki-Holland S, Gittoes N, Hewison M, et al. Trends in the incidence of testing for vitamin D deficiency in primary care in the UK: a retrospective analysis of The Health Improvement Network (THIN), 2005-2015. BMJ Open. 2019;9(6):e028355-e.

127. Bates B, Cox L, Nicholson S, Page P, Prentice A, Steer T, et al. National Diet and Nutrition Survey results from years 5 and 6 (combined) of the Rolling Programme (2012/2013-2013/2014). London: Public Health England. 2016.

\section{Figure Legend}

Figure 1: The metabolic pathway of vitamin D synthesis and the tissue specific cellular response it mediates that may reduce COVID-19 severity. CYP2R1, CYP27A1, and CYP27B1 are the cytochrome enzymes involve in the hydroxylation processes of cholecalciferol to the active form of vitamin $\mathrm{D}, 1,25(\mathrm{OH})_{2} \mathrm{D} .1,25(\mathrm{OH})_{2} \mathrm{D}$ then binds to VDR which forms a heterodimer with retinoid X receptor (RXR). Interaction of the heterodimer with the vitamin D response element (VDRE) leads to downstream target gene regulation.
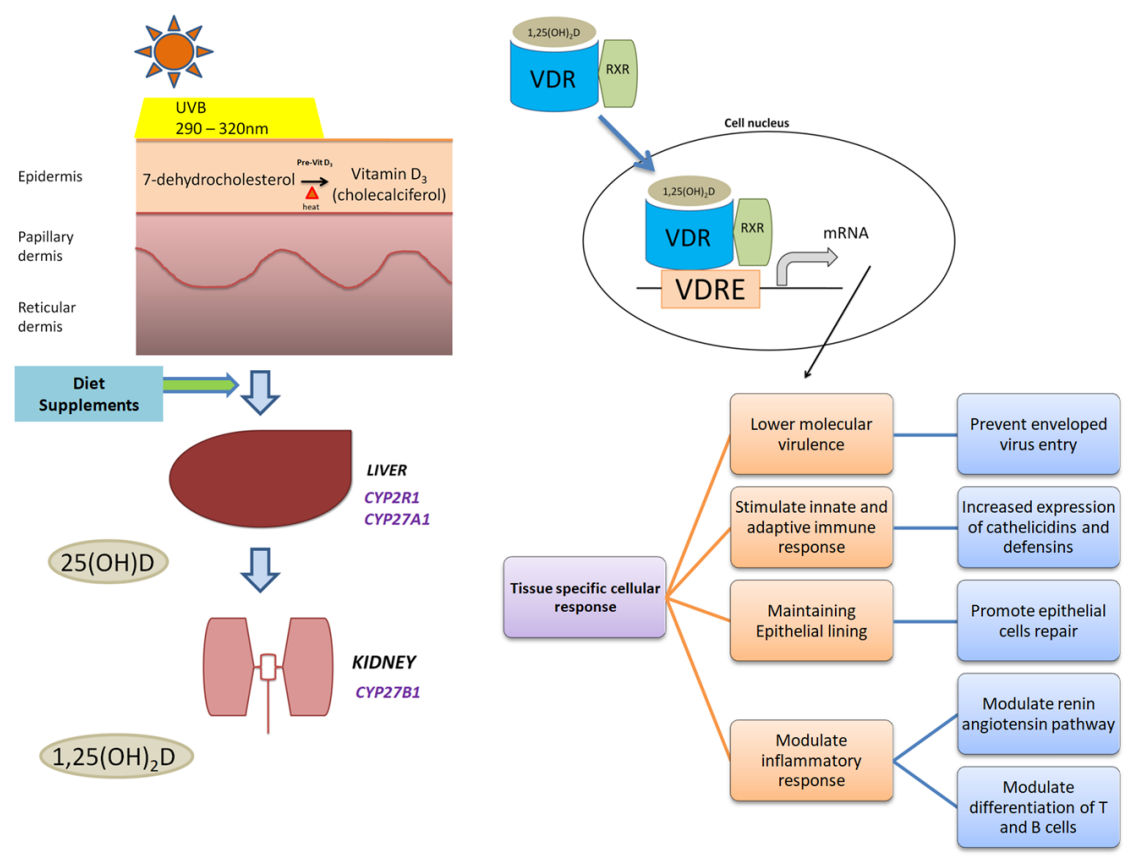